\title{
Is waste collection associated with hepatitis B infection? A meta-analysis
}

\author{
Marcos Paulo Gomes Mol[1],[2], Sandy Cairncross ${ }^{[3]}$, \\ Dirceu Bartolomeu Greco ${ }^{[4]}$ and Leo Heller ${ }^{[5]}$
}

\author{
[1]. Diretoria de Pesquisa e Desenvolvimento, Fundação Ezequiel Dias, Belo Horizonte, MG, Brasil. \\ [2]. Departamento de Engenharia Sanitária e Ambiental, Universidade Federal de Minas Gerais, Belo Horizonte, MG, Brasil. \\ [3]. Department of Disease Control, London School of Hygiene and Tropical Medicine, London, England. \\ [4]. Faculdade de Medicina, Universidade Federal de Minas Gerais, Belo Horizonte, MG, Brasil. \\ [5]. Centro de Pesquisas René Rachou, Fundação Oswaldo Cruz, Belo Horizonte, MG, Brasil.
}

\begin{abstract}
This meta-analysis, which is based on a previously published systematic review, aims to contribute to the scientific discussion on hepatitis B virus (HBV) infection in workers who are exposed to domestic and healthcare wastes. Publications were sought which had been made available on the data used by December 2013 and updated to December 2016. The quality of the included studies was assessed according to the guidelines of Loney et al. for the critical appraisal of studies on the prevalence or incidence of a health problem. To verify the presence of heterogeneity between the papers, we used the Chi-squared test based on a $\mathrm{Q}$ statistic. A funnel plot was used to test for publication bias. All included studies had across-sectional study design. The association between exposure to waste and positive serology for the HBV surface antigen (HBsAg) showed a significant association [odds ratio (OR) $1.89,95 \%$ confidence interval (CI) $1.27-2.86 ; \mathrm{p}=0.0019]$. The prevalence rates of HBsAg and anti-HBc seropositivity was $0.04(95 \%$ CI $0.03-0.05)$ and $0.21(95 \%$ CI $0.14-0.28)$, respectively $(\mathrm{p}<0.0001)$. We found no evidence of publication bias. The results of this meta-analysis indicate a statistically significant association between exposure to solid waste, whether healthcare or domestic, and positive HBV infection markers. Therefore, the working conditions of waste collectors should be analyzed more closely. Immunization against HBV is recommended as the chief preventive measure for all solid waste workers.
\end{abstract}

Keywords: Meta-analysis. Hepatitis B. Waste workers. Domestic waste. Healthcare waste.

\section{INTRODUCTION}

Workers involved in the collection, transport, and disposal of urban waste are in physical contact with waste materials and, because of this, are exposed to biological, chemical, and physical risks to their health. Many countries, in particular developing countries, still adopt a rudimentary waste collection systems, and waste collectors are at increased risk because of this precarious systems. Occupational hazards include various pathogens such as bacteria, fungi, viruses and parasites, toxic chemicals, and also factors such as excess noise, exposure to sunlight, and muscle strains. A particular risk is injury by infected sharps ${ }^{1-3}$.

It has been estimated that accidents involving sharps cause a worldwide total of approximately 66,000 and 16,000 cases of hepatitis B virus (HBV) and hepatitis $\mathrm{C}$ virus (HCV) infections, respectively, per year ${ }^{4,5}$.

Hepatitis B virus may be found in body secretions and excreta. The virus shows environmental persistence, and a

Corresponding author: Dr. Marcos Paulo Gomes Mol.

e-mail: marcos.mol@funed.mg.gov.br

Received 4 April 2017

Accepted 21 September 2017 very small dosage is sufficient to cause infection ${ }^{6}$. Workers collecting solid wastes can be at risk of HBV infection due to the characteristics of the wastes.

Two literature reviews have been published on this subject ${ }^{7,8}$, but differences were found between the papers included in those reviews in comparison with this present meta-analysis paper, in particular because of the number and quality of the included papers. Four cross-sectional studies corresponded to the articles selected in this meta-analysis ${ }^{9-12}$. Only few systematic reviews were found on $\mathrm{HBV}$ infection associated with the collection of solid wastes, whether domestic or healthcare waste. The present review seeks to fill that gap. The aim of this meta-analysis was to contribute to the scientific discussion on HBV infection in workers who collect solid wastes, with a focus on the similarities between risks of exposure to domestic and healthcare waste.

\section{METHODS}

\section{Search strategy}

The details of the search strategy that was used by the literature review which was the basis for this meta-analysis have been published previously ${ }^{13}$. Publications were sought which were available by December 2013 on the data banks 
used, and updated until December 2016 to cover recent scientific publications. We used pairs of search terms (one referring to hepatitis B and the other to occupational exposure to waste), together with the number of articles elicited by each pair, to conducted the searches, as published previously ${ }^{13}$.

All methods followed the PRISMA (Preferred Reporting Items for Systematic Reviews and Meta-Analyses) guidelines ${ }^{14}$.

\section{Outcomes}

Odds ratios (OR) with $95 \%$ confidence intervals (CI) and the prevalence of $\mathrm{HBV}$ infection were used as summary measures in all meta-analyses.

\section{Study selection}

Publications in English, Italian, Portuguese, and Spanish were considered eligible for inclusion. All studies were included in which the health outcome was infection with hepatitis B virus in workers who collect domestic or healthcare solid waste. Exclusion criteria covered mainly: 1) Studies of populations who did additional work besides waste collection (typically, healthcare staff at hospitals such as physicians and nurses) because the risks related to waste exposure were likely different in these workers; and 2) Studies that did not quantitatively assess the risk of HBV infection or only assessed other outcomes (e.g., those who only used qualitative methods based on the workers' perception of the health risks associated with waste collection). Papers excluded at the full reading step and the reasons for their exclusion were registered. No criterion was set regarding the size or gender of the study population, or the epidemiological design of studies to be included.

\section{Data extraction}

Articles retrieved were first screened by their titles, and then by reading their abstracts. The full text of those meeting the inclusion criterion was then read. The databases were searched for publications with the various possible pairs of search terms, one referring to HBV and the other to their exposure to waste, together with the number of articles elicited by each pair, as shown elsewhere ${ }^{13}$.

We extracted the following study characteristics: study design; year of publication; sample size; type of wastes handled (form of exposure); type of outcome indicator used (HBV); sociodemographic data; type of exposure reported by the workers; and study limitations.

Discrepancies were discussed until a consensus was reached. Studies that reported datasets from different settings were eligible for inclusion. All data on ORs and the prevalence of HBV infection were included in the meta-analysis model and calculated based on $2 \times 2$ tables.

\section{Quality assessment}

The quality of each paper was assessed according to the guidelines for the critical appraisal of studies on the prevalence or incidence of a health problem ${ }^{15}$. We adopted this specific tool to analyze prevalence data because all included studies had a cross-sectional study design ${ }^{15}$. The score includes eight components that each refer to one aspect of the study methods: study design, sampling method, sample size, standard criteria used, outcome measure, response rate, confidence intervals, and setting described. One point was given to each aspect that was found adequate according to the quality criteria. The score for each paper thus ranged from zero to eight points. The minimum score for a paper to be included in the meta-analysis was four points. We registered the articles that were selected for inclusion in this meta-analysis and their full quality criteria.

\section{Heterogeneity and publication bias}

To verify the presence of heterogeneity between the papers, the Chi-Square test based on a $\mathrm{Q}$ statistic was adopted. The random effect model was used when heterogeneity was found between the studies. The fixed effect model was used when no heterogeneity was found. The tests adopted for HBV varied according to each article, most of which used HBsAg (to identify incubating, acute or chronic disease) and Anti-HBc (to identify the stage of the disease, not including incubation, but additionally including those who have recovered). HBV serology results were presented individually.

A funnel plot was used to test for publication bias $^{16}$ and a forest plot to estimate the main results in a ln scale (OR) or as prevalence.

All analyses were conducted using the R software, version 3.4. $0^{17}$, metafor package.

\section{RESULTS}

The search was carried out from January to December 2013 and updated to December 2016, identifying 17 papers that met the requirements for inclusion in the systematic review. The flow diagram and other details about the systematic search were published prevoiusly ${ }^{13}$. A total of 35 articles were selected for full-text screening; of these, 17 were excluded as the study populations did additional work besides waste collection (typically, they were healthcare staff such as physicians and nurses working at hospitals). Moreover, 27 duplicate articles were excluded. Table 1 shows the characteristics of all included papers, with the quality scores and limitations.

All studies had a cross-sectional study design; this limits their ability to establish causality as they contain no information on the relative timing of the exposure and the outcome(s).

Figure 1 presents a forest plot of Odds Ratios from selected studies, showing the effect of exposure to wastes on HBsAg. For this model, just eleven papers (using HBsAg as the outcome) were included in this model. Heterogeneity was not found between the papers $(\mathrm{p}=0.22)$. A fixed-effects model was therefore adopted. Exposure to waste showed a significant association with HBsAg-positive serology (OR 1.89, 95\% CI 1.27-2.86).

We found no asymmetry in the funnel plot (Figure 2), indicating no evidence of publication bias. A linear regression analysis was used to confirm the absence of publication bias $(\mathrm{p}=0.11)$.

Figure 3 and Figure 4 show the distribution of positive serology for HBsAg and anti-HBc among workers exposed to waste. Heterogeneity was found between the papers 
TABLE 1: Articles selected for inclusion in the meta-analysis (in chronological order of publication).

\begin{tabular}{|c|c|c|c|c|c|}
\hline $\begin{array}{l}\text { Author (year; } \\
\text { country) }\end{array}$ & $\begin{array}{l}\text { Sample } \\
\text { size }\end{array}$ & Study groups & $\begin{array}{l}\text { Outcome } \\
\text { measure* }\end{array}$ & $\begin{array}{l}\text { Quality } \\
\text { score }^{\star *}\end{array}$ & Limitations** \\
\hline $\begin{array}{l}\text { Amsalu A et al. } \\
\text { (2016; Ethiopia })^{18}\end{array}$ & 234 & $\begin{array}{l}152 \mathrm{HCW} \text { and } 82 \\
\text { non-HCW handlers }\end{array}$ & $\begin{array}{l}\text { HBV (HBsAg, anti- } \\
\text { HBc) }\end{array}$ & 6 & $\begin{array}{l}\text { Biased sampling frame and outcomes } \\
\text { measured by biased assessors }\end{array}$ \\
\hline $\begin{array}{l}\text { Moghaddam AA et } \\
\text { al. }(2016 ; \text { Iran })^{19}\end{array}$ & 654 & $\begin{array}{l}178 \text { USW and } 476 \text { non- } \\
\text { USW workers }\end{array}$ & HBV (HBsAg) & 6 & $\begin{array}{l}\text { Biased sampling frame and outcomes } \\
\text { measured by biased assessors }\end{array}$ \\
\hline $\begin{array}{l}\text { Mol MPG et al. } \\
(2016 ; \text { Brazil })^{20}\end{array}$ & 522 & $\begin{array}{l}61 \mathrm{HCW} \text { workers and } 461 \\
\text { who collect only domestic } \\
\text { waste }\end{array}$ & $\begin{array}{l}\text { HBV (HBsAg, anti- } \\
\mathrm{HBc} \text {, anti-HBs) }\end{array}$ & 6 & $\begin{array}{l}\text { Biased sampling frame and outcomes } \\
\text { measured by biased assessors }\end{array}$ \\
\hline
\end{tabular}

El-Wahab EWA et al. (2015; Egypt) $)^{21}$

Tsovili E et al. (2014; Greece $)^{22}$

Ewis AA et al. (2013; Egypt $)^{23}$

Anagaw B et al. (2012; Ethiopia) ${ }^{24}$

Rachiotis $\mathrm{G}$ et al. (2012; Greece $)^{10}$

Shiferaw $Y$ et al. (2011; Ethiopia) ${ }^{25}$
186 USW and 160 nonUSW workers

50 USW workers and 83 unexposed individuals (different occupations)

138 USW and 127 nonUSW workers

$100 \mathrm{HCW}$ workers (hospital) and 100 cleaning HBV (HBsAg) waste)

100 domestic waste collectors and 108 gardeners

$126 \mathrm{HCW}$ workers

(hospital) and 126 workers HBV (HbsAg, anticollecting normal (nonclinical) waste at a hospital

64 landfill workers, 41 USW workers, 35 sweepers, 45 drivers, and 32 controls (railway maintenance)

$300 \mathrm{HCW}$ workers (medical center) and 300 collecting only domestic waste

HBV (HBsAg, anti$\mathrm{HBc}$, anti-HBs)

HBV (HBsAg, anti$\mathrm{HBc}$, anti-HBs)

HBV (HBsAg, anti$\mathrm{HBc}$, anti-HBs)

$\mathrm{HBc}$ )

HBV (anti-HBc)

HBV (HBsAg)

169 domestic waste workers and 185 public cleaning workers (not in direct contact with waste)

HBV (HBsAg, anti-
Biased sampling frame, outcomes measured by biased assessors, and confidence intervals or subgroup analysis

Biased sampling frame, adoption of nonstandard measures, outcomes measured by biased assessors, and confidence intervals or subgroup analysis

Outcomes measured by biased assessors confidence intervals or subgroup analysis

Outcomes measured by biased assessors, inadequate confidence intervals or subgroup analysis.

Biased sampling frame, inadequate sample size, outcomes measured by biased assessors.

Biased sampling frame, inadequate sample size, outcomes measured by biased assessors, inadequate confidence intervals or subgroup analysis

Outcomes measured by biased assessors inadequate confidence intervals or subgroup analysis

Biased sampling frame, inadequate sample size, outcomes measured by biased assessors, inadequate confidence intervals or subgroup analysis

Continue...... 
TABLE 1: Continuation.

\begin{tabular}{|c|c|c|c|c|c|}
\hline $\begin{array}{l}\text { Author (year; } \\
\text { country) }\end{array}$ & $\begin{array}{l}\text { Sample } \\
\text { size }\end{array}$ & Study groups & $\begin{array}{l}\text { Outcome } \\
\text { measure* }\end{array}$ & $\begin{array}{l}\text { Quality } \\
\text { score**}^{* *}\end{array}$ & Limitations ${ }^{* *}$ \\
\hline $\begin{array}{l}\text { Squeri R et al. } \\
(2006 \text {; Italy })^{12}\end{array}$ & 327 & $\begin{array}{l}\text { Domestic waste workers } \\
\text { only }\end{array}$ & $\begin{array}{l}\text { HBV (HBsAg, anti- } \\
\mathrm{HBC})\end{array}$ & 4 & $\begin{array}{l}\text { Biased sampling frame, inappropriate } \\
\text { measurement of health outcome, } \\
\text { outcomes measured by biased assessors, } \\
\text { inadequate confidence intervals or } \\
\text { subgroup analysis. }\end{array}$ \\
\hline $\begin{array}{l}\text { Mariolis A et al. } \\
(2006 ; \text { Greece })^{29}\end{array}$ & 69 & $\begin{array}{l}\text { Domestic waste workers } \\
\text { only }\end{array}$ & $\begin{array}{l}\text { HBV (HBsAg, anti- } \\
\text { HBs, anti-HBc) }\end{array}$ & 4 & $\begin{array}{l}\text { Biased sampling frame, inadequate } \\
\text { sample size, outcomes measured by } \\
\text { biased assessors, inadequate confidence } \\
\text { intervals or subgroup analysis }\end{array}$ \\
\hline $\begin{array}{l}\text { Ferreira JA et al. } \\
(1999 ; \text { Brazil })^{30}\end{array}$ & 186 & $\begin{array}{l}31 \mathrm{HCW} \text { collectors } \\
\text { (hospitals) and } 155 \\
\text { domestic waste workers }\end{array}$ & HBV (anti-HBc) & 5 & $\begin{array}{l}\text { Inadequate sample size, outcomes } \\
\text { measured by biased assessors, } \\
\text { inadequate confidence intervals or } \\
\text { subgroup analysis }\end{array}$ \\
\hline $\begin{array}{l}\text { Corrao G et al. } \\
(1985 ; \text { Italy })^{9}\end{array}$ & 93 & $\begin{array}{l}45 \text { sweepers, } 21 \text { waste } \\
\text { collectors, } 19 \text { machine } \\
\text { operators, } 5 \text { sewer workers } \\
\text { and } 3 \text { office workers. }\end{array}$ & $\begin{array}{l}\text { HBV (HBsAg, anti- } \\
\text { HBs, anti-HBc). }\end{array}$ & 4 & $\begin{array}{l}\text { Biased sampling frame, inadequate } \\
\text { sample size, outcomes measured by } \\
\text { biased assessors, inadequate confidence } \\
\text { intervals or subgroup analysis }\end{array}$ \\
\hline
\end{tabular}

anti-HBc: hepatitis B core antibody; anti-HBs: hepatitis B surface antibody; HbsAg: hepatitis B surface antigen; HBV: hepatitis B virus; HCW: healthcare waste; USW: urban solid waste. *Sensitivities of the serological tests for hepatitis B: anti-HBc - detects acute, chronic, cure stages; HbsAg - detects incubation, acute, chronic stages; and anti-HBs analyzes a person's vaccination status. ${ }^{* *}$ According to the guidelines of Loney et al. for the critical appraisal of studies on the prevalence or incidence of a health problem.

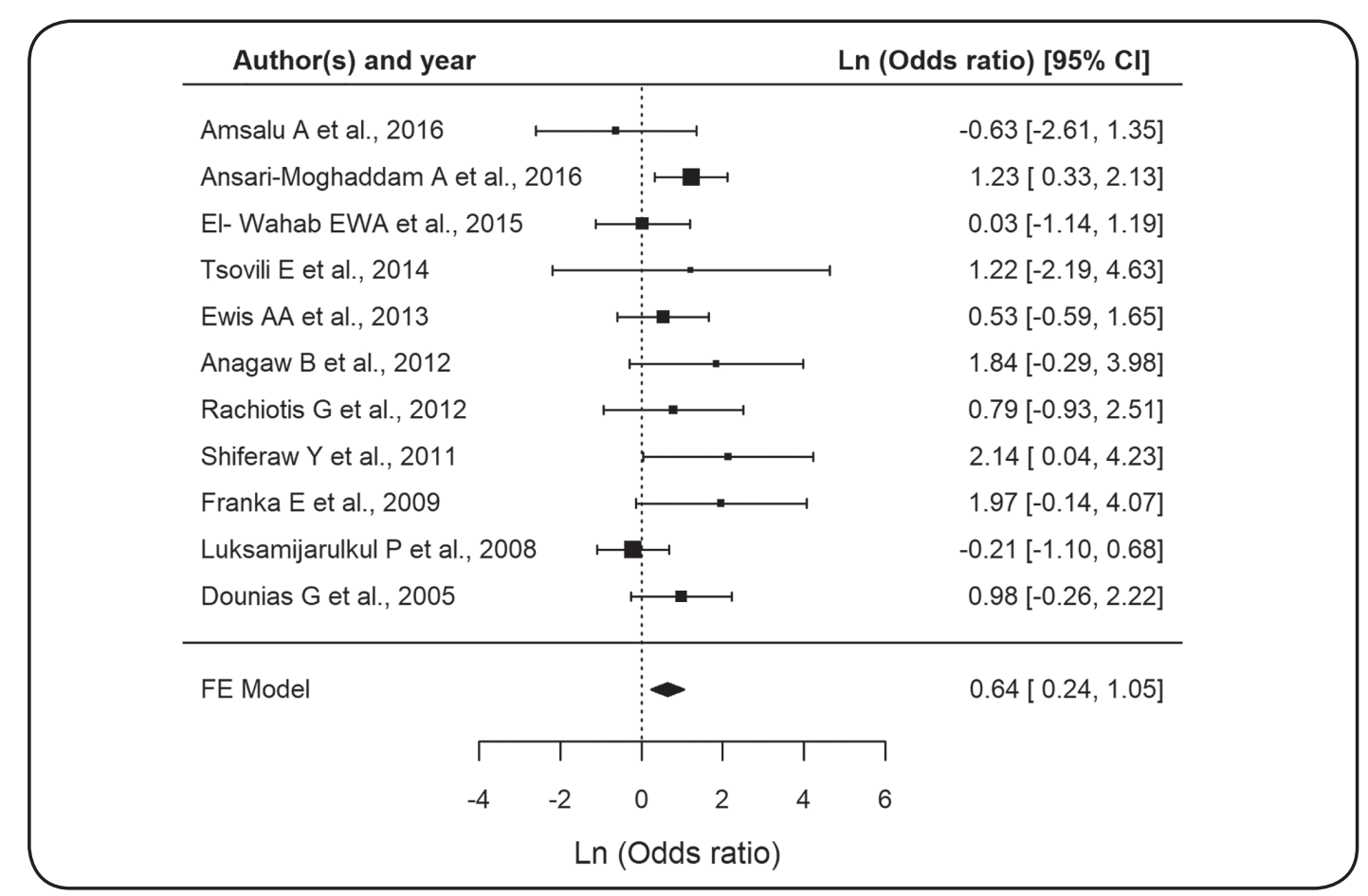

FIGURE 1 - Forest plot estimating the effects of exposure to waste on HBsAg serology. The right side of the forest plot indicates a stronger association between exposure to waste and HBsAg positive serology. HBsAg: hepatitis B surface antigen; Cl: confidence interval; FE model: fixed effect model; Ln: logarithm. 


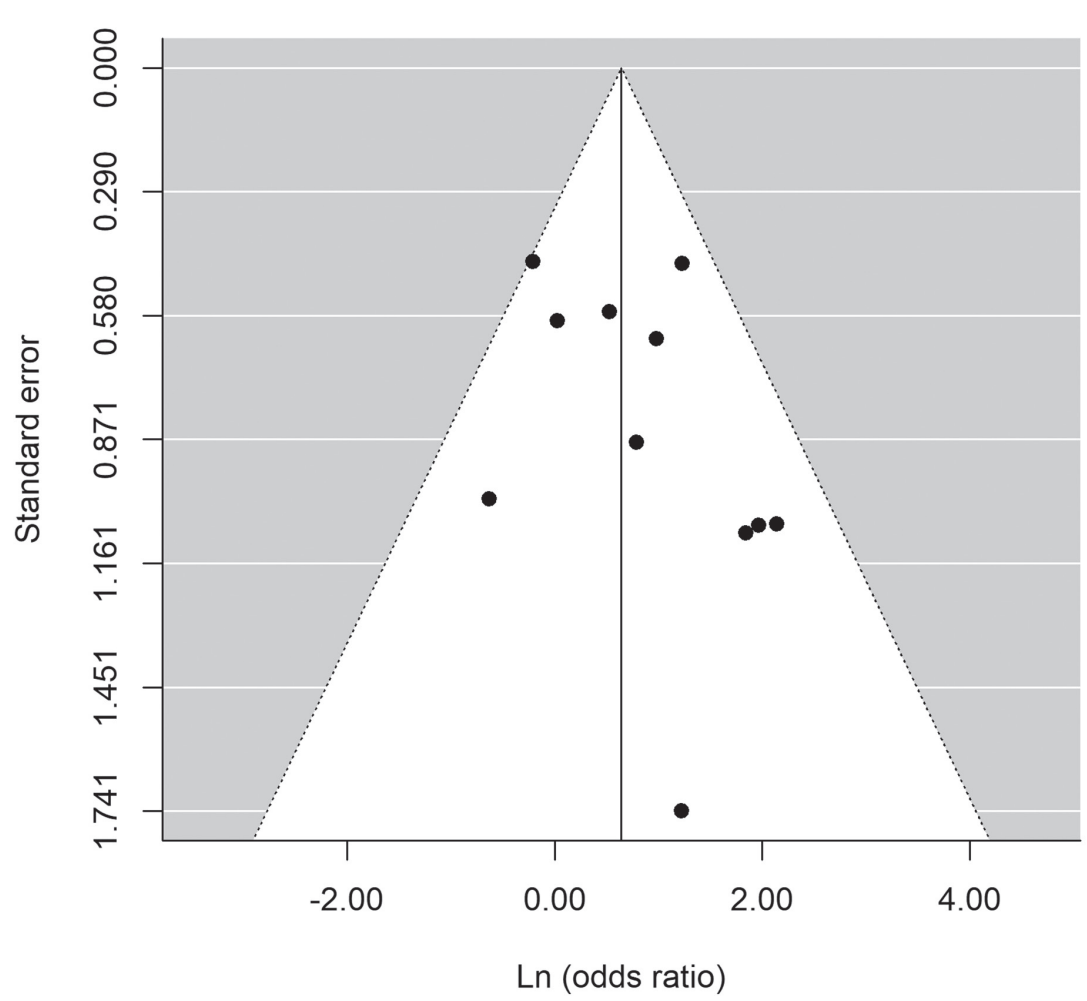

FIGURE 2 - Funnel plot of included studies, according to HBsAg serology. HBsAg: hepatitis B surface antigen; Ln: logarithm.

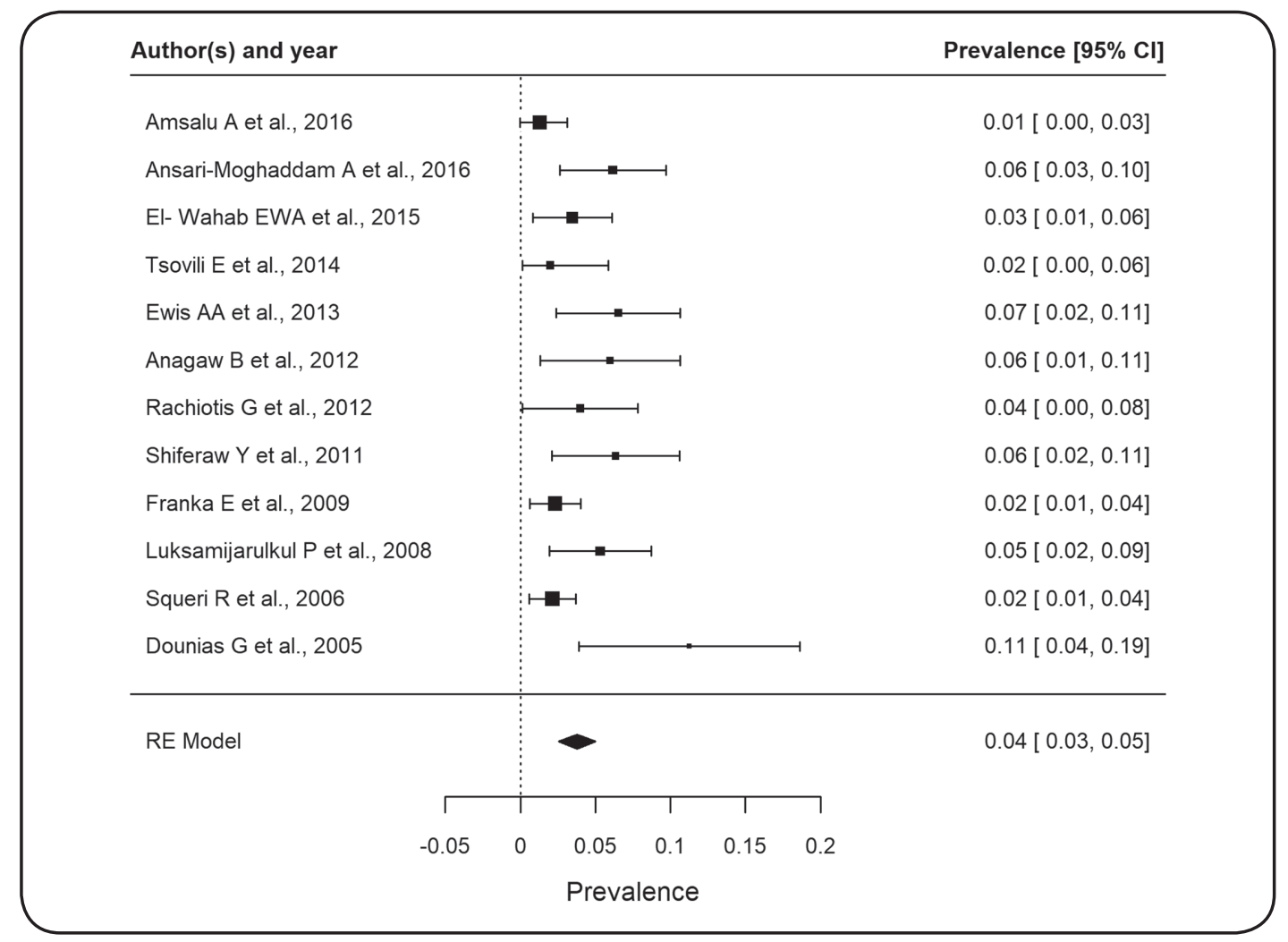

FIGURE 3 - Forest plot estimating the prevalence of HBsAg serology. The right side of the plot indicates a higher prevalence of HBsAg serology. HBsAg: hepatitis B surface antigen; Cl: confidence interval; RE model: random effect model. 


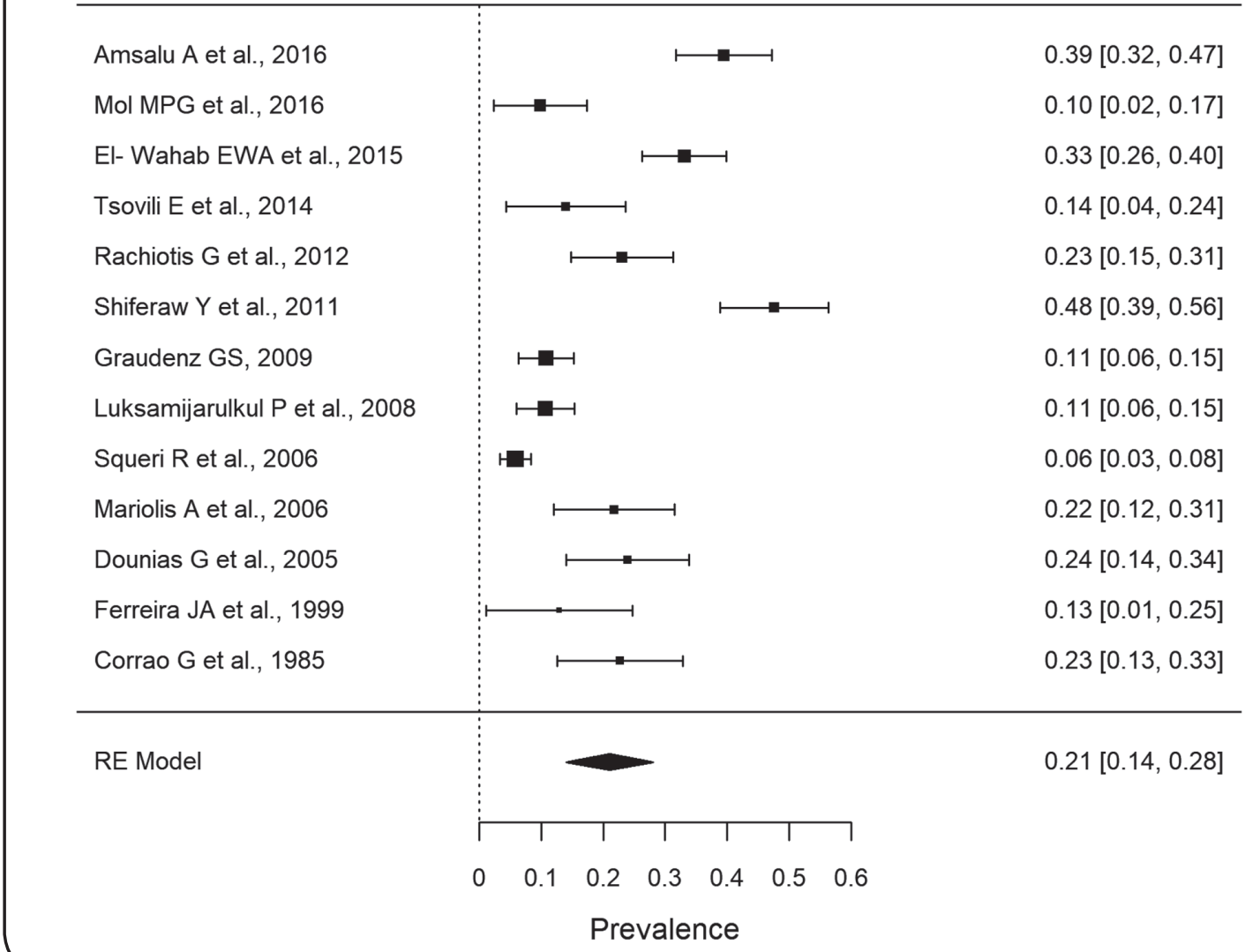

FIGURE 4 - Forest plot estimating the prevalence of total anti-HBc serology. The right side of the plot indicates a higher prevalence of anti-HBc serology. anti-HBc: hepatitis B core antibody; $\mathrm{Cl}$ : confidence interval; RE model: random effect model.

( $p=0.023$ and $\mathrm{p}<0.0001$ for HBsAg and anti-HBc, respectively). Therefore, a random effects models was used for both. The rate of HBsAg and anti-HBc seropositivity in workers exposed to waste was 0.04 (95\% CI 0.03-0.05) and 0.22 (95\% CI 0.14$0.30)$, respectively.

\section{DISCUSSION}

This meta-analysis included studies of workers collecting domestic or healthcare wastes. Most studies compared workers who were exposed to waste with those who were not. Eleven studies compared workers collecting solid domestic waste

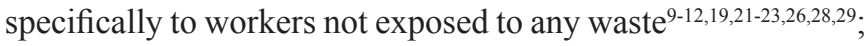
four compared workers exposed to healthcare waste to those exposed to uninfected waste from hospitals $\mathbf{s}^{18,24,25,27}$. Uninfected waste differs from domestic waste as the latter often contains blood or other bodily fluids. Workers collecting waste within hospital environments are usually less exposed to infection risks than those who collect domestic waste because of the differences between these types of waste. Only two papers compared workers exposed to domestic waste to those exposed to healthcare waste ${ }^{20,30}$. The distinction between the types of wastes is relevant when comparing these studies.
Two studies ${ }^{12,29}$ exclusively analyzed workers exposed to domestic waste and did not undertake serological surveys of other groups of workers. Some studies compared workers exposed to domestic waste with controls such as gardeners, railway maintenance workers, cleaners, and office workers, all of whom did not have direct contact with waste.

We identified several methodological limitations of the 17 studies included in this meta-analysis. All used a cross-sectional study design, constraining the assessment of a cause-andeffect relationship by failing to identify the moment at which the infection occurred. The small number of selected papers and the low numbers of workers seropositive for hepatitis B in some studies represented a statistical limitation, although a statistically significant difference was found. Few publications were found which focused on HBV infection in waste collectors. Other limitations might be associated with social factors, such as poverty, as most studies were conducted in countries where waste collection is considered a job for those without better work opportunities. Hazardous environmental conditions are often present and conditions are particularly dangerous in places where the poorest live, work, or visit ${ }^{31}$.

Some studies have suggested that immunization against HBV and being under treatment for the disease should be exclusion criteria to mitigate any possible selection bias. This 
was mainly suggested by older studies and those conducted in countries where HBV immunization has only recently been implemented. In both cases, the studies showed the vulnerability of workers who are at risk of HBV infection while doing their job without the appropriate immunization. On one hand, the set of included studies raises methodological questions regarding the study design. On the other hand, it reflects the susceptibility of workers who are exposed to waste to HBV infection ${ }^{10,11,25,26,30}$.

The sample size adopted in selected papers was analyzed according to the guidelines by Loney et al. ${ }^{15}$ for comparing the prevalence in exposed and non-exposed subjects (Table 1). Eight studies ${ }^{9-11,22,26,28-30}$ did not have an adequate sample size to ensure statistical significance, whereas the remaining nine studies $^{12,18-21,23-25,27}$ had adequate sample sizes ${ }^{32}$.

Recall bias is also relevant, albeit infrequently mentioned in the included publications. In some cases, the study participants might not have been able to recall all information regarding past exposures during an interview. They might have also found it difficult to answer some interview questions, particularly those related to sexual behaviour ${ }^{10,12,18,20,24-28}$. Surprisingly, few respondents outright refused to answer these questions.

We also assessed if the studies used models that controlled for possible confounding factors such as sexual behavior, injection drug use, and a history of tattooing; for waste collection workers, accidents involving injuries caused by sharps or exposure to blood/bodily fluids should be additionally included in the model. Eight studies $9,12,21-23,26,27,29$ did not describe any methods to control for confounding factors. Some studies presented calculations for identifying factors such as the workers' general health status ${ }^{26}$ and their use of individual protective equipment ${ }^{27}$.

Only one study ${ }^{28}$ analyzed the association between HBV infection and factors such as a history of tattooing, accidents with sharps, use of syringes, and exposure to solid wastes; the authors found a statistically significant for all variables except a history of tattooing.

Our meta-analysis models showed a statistically significant association between exposure to wastes, healthcare or domestic, and HBsAg seropositivity. Therefore, exposure to both types of waste likely puts workers at risk of infection. Only two selected papers compared workers exposed to healthcare waste to those exposed to domestic wastes; they did not find differences in hepatitis B prevalence between the two groups ${ }^{20,30}$.

In this meta-analysis, we found a prevalence of HBV infection (positive serology for $\mathrm{HBsAg}$ or anti-HBc) of $4 \%$ and $21 \%$, for $\mathrm{HBsAg}$ and anti-HBc, respectively. The rate of HBsAg seropositivity found in this study is similar to the global intermediate rate of $2-8 \%$, according to data of the World Health Organization ${ }^{33}$. In Brazil, the rate of HBsAg seropositivity was $0.37 \%(95 \% \text { CI } 0.25-0.50 \%)^{34}$. The rate of anti-HBc seropositivity in Northern Brazil, an epidemic region for $\mathrm{HBV}$, was $10.9 \%(95 \% \mathrm{CI} 8.87-12.9 \%)^{34}$. Our meta-analysis, which included both, studies published 31 years ago and recent studies, indicates a high risk of HBV infection associated with exposure to waste, according to the serology data.

The working conditions of waste collectors should be analyzed in more detail; specifically, studies should distinguish between workers who collect healthcare and those who collect domestic waste. Accidents involving sharps (mainly related to healthcare waste) were associated with $45.7 \%$ of all occurrences in a healthcare establishment, mainly involving healthcare waste ${ }^{35}$, and inappropriate segregation of sharps was associated with $15.4 \%$ of accidents in another study ${ }^{36}$. A third study ${ }^{37}$ found that, of all accidents reported in a healthcare establishment, $54.6 \%$ were caused by cuts and were registered as occurring during the disposal of healthcare waste. The high rates of injuries involving sharps represent a health risk for workers collecting healthcare waste.

Healthcare waste is typically divided into several categories based on the characteristics of the waste and the related health risks: infectious materials, toxic chemicals, radioactive substances, and waste related to a risk of cuts. Some healthcare waste is generated in offices and thus does not pose any health risks. This common healthcare waste is different than domestic waste (which is often mixed with blood or bodily fluids). Some studie $^{24,25,27}$ included in this meta-analysis compared workers exposed to infected healthcare waste to those exposed to common healthcare waste and found differences in prevalence between the two groups.

In conclusion, this meta-analysis shows that handling healthcare and domestic waste is associated with a similar risk of HBV infection. The effect of exposure to waste on workers' health, and in particular on the risk of HBV infection, in both domestic and healthcare settings is increasingly supported by scientific evidence. The search for specific indicators to prove such an association is a challenge to future research, and also to programme managers seeking to protect their staff and the public. The increased risk of HBV infection associated with the handling of solid waste, as shown in this meta-analysis, highlights the right of waste workers to immunization against $\mathrm{HBV}$ as a primary preventive measure.

\section{Acknowledgments}

We acknowledge the research incentives and financial support provided by the Fundação Ezequiel Dias (Funed), Fundação de Amparo à Pesquisa do Estado de Minas Gerais (FAPEMIG), and Conselho Nacional de Desenvolvimento Científico e Tecnológico (CNPq).

\section{Conflict of interest}

The authors declare that there is no conflict of interest.

\section{REFERENCES}

1. Porta D, Milani S, Lazzarino AI, Perucci CA, Forastiere F. Systematic review of epidemiological studies on health effects associated with management of solid waste. Environ Health. 2009;8:60.

2. Rushton L. Health hazards and waste management. Br Med Bull. 2003;68:183-97.

3. Domingo JL, Nadal M. Domestic waste composting facilities: A review of human health risks. Environ Int. 2009;35(2):382-9.

4. Pruss-Ustun A, Rapiti E, Hutin Y. Sharps injuries: Global burden of disease fromsharps injuries to health-careworkers. Environmental 
burden of disease series No. 3. Geneva: World Health Organization; 2003. 48 p.

5. Ghannad MS, Majzoobi MM, Ghavimi M, Mirzaei M. Needlestick and sharp object injuries among health care workers in Hamadan Province, Iran. J Emerg Nurs. 2012;38(2):171-5.

6. Sattar SA, Tetro J, Springthorpe VS, Giulivi A. Preventing the spread of hepatitis B and C viruses: Where are germicides relevant? Am J Infect Control. 2001;29(3):187-97.

7. Tooher R, Griffin T, Shute E, Maddern G. Vaccinations for wastehandling workers. A review of the literature. Waste Manage Res. 2005;23(1):79-86.

8. Corrao CRN, Del Cimmuto A, Marzuillo C, Paparo E, La Torre G. Association between Waste Management and HBV among Solid Municipal Waste Workers: A Systematic Review and Meta-Analysis of Observational Studies. Scientific World J. 2013;2013 Article ID 692083.

9. Corrao G, Zotti C, Sciacovelli A, Bosia S, Piccioni P. Infezioni da virus delle epatiti A e B negli addetti alla raccolta rifiuti di Asti. G Ital Med Lav. 1985;7:145-7.

10. Rachiotis G, Papagiannis D, Markas D, Thanasias E, Dounias G, Hadjichristodoulou C. Hepatitis B virus infection and waste collection: Prevalence, risk factors, and infection pathway. Am J Ind Med. 2012;55(7):650-5.

11. Dounias G, Kypraiou E, Rachiotis G, Tsovili E, Kostopoulos S. Prevalence of hepatitis B virus markers in municipal solid waste workers in Keratsini (Greece). Occup Med. 2005;55(1):60-3.

12. Squeri R, Fauci VL, Sindoni L, Cannavo G, Spagnolo EV. Study on hepatitis $\mathrm{B}$ and $\mathrm{C}$ serologic status among municipal solid waste workers in Messina (Italy). J Prev Med Hyg. 2006;47:110-3.

13. Mol MPG, Greco DB, Cairncross S, Heller L. Hepatitis B and C in household and health services solid waste workers. Cad Saude Publica. 2015;31(suppl 1):S295-S300.

14. Moher D, Liberati A, Tetzlaff J, Altman DG, PRISMA Group. Preferred reporting items for systematic reviews and meta-analyses: the PRISMA statement. PLoS Med. 2009;6(7):e1000097.

15. Loney PL, Chambers LW, Bennett KJ, Roberts GR, Stratford PW. Critical appraisal of the health research literature: prevalence or incidence of a health problem. Chronic Dis Can. 1998;19(4):170-6.

16. Light RJ, Pillemer DB. Summing up: The science of reviewing research. Cambridge; Harvard University Press; 1984. p. 191.

17. Viechtbauer W. Conducting Meta-Analyses in $\mathrm{R}$ with the metafor Package. J Stat Softw. 2010;36(3):1-48.

18. Amsalu A, Worku M, Tadesse E, Shimelis T. The exposure rate to hepatitis $\mathrm{B}$ and $\mathrm{C}$ viruses among medical waste handlers in three government hospitals, southern Ethiopia. Epidemiol Health. 2016;38:e2016001.

19. Ansari-Moghaddam A, Ansari H, Khosravi S, Sanei-Moghaddam E, Mohammadi M, Alavian S, et al. The Prevalence of Hepatitis B Virus Among Municipal SolidWaste Workers: Necessity for Immunization of At-Risk Groups. Hepat Mon. 2016;16(3):e30887.

20. Mol MPG, Gonçalves JP, Silva EA, Scarponi CFO, Greco DB, Cairncross S, et al. Seroprevalence of hepatitis B and C among domestic and healthcare waste handlers in Belo Horizonte, Brazil. Waste Manag Res. 2016;34(9):875-83.

21. El-Wahab EWA, Eassa SM, Lotfi SE, Kotkat AM, Shatat HZ, El Masry SA. Seroprevalence, Immunostatus and Factors Associated with Blood Borne Viral Infections Among Egyptian Municipal Solid Waste Workers. J Virol Antivir Res. 2015;4(4):1-8. doi:10.4172/23248955.1000144 .
22. Tsovili E, Rachiotis G, Symvoulakis E, Thanasias E, Giannisopoulou $\mathrm{O}$, Papagiannis D, et al. Municipal waste collectors and hepatitis $B$ and $C$ virus infection: a cross-sectional study. Infez Med. 2014;22(4):271-6.

23. Ewis A, Rahma M, Mohamed E, Hifnawy T, Arafa A. Occupational health-related morbidities among street sweepers and waste collectors at Beni-Suef, Egypt. Egyptian Journal of Occupational Medicine. 2013;37(1):79-94.

24. Anagaw B, Shiferaw Y, Anagaw B, Belyhun Y, Erku W, Biadgelegn $F$, et al. Seroprevalence of hepatitis $B$ and $C$ viruses among medical waste handlers at Gondar town Health institutions, Northwest Ethiopia. BMC Res Notes. 2012;5:55. doi: 10.1186/1756-0500-5-55.

25. Shiferaw Y, Abebe T, Mihret A. Short Report. Hepatitis B virus infection among medical waste handlers in Addis Ababa, Ethiopia. BMC Res Notes. 2011;4:479.

26. Graudenz GS. Indicadores infecciosos e inflamatórios entre trabalhadores da limpeza urbana em São Paulo. Rev Bras Saúde Ocup. 2009;34(120):106-14.

27. Franka E, El-Zoka AH, Hussein AH, Elbakosh MM, Arafa AK, Ghenghesh KS. Hepatitis B virus and hepatitis $\mathrm{C}$ virus in medical waste handlers in Tripoli, Libya. J Hosp Infect. 2009;72(3):258-61.

28. Luksamijarulkul P, Sujirarat D, Charupoonphol P. Risk behaviors, occupational risk and seroprevalence of hepatitis $\mathrm{B}$ and $\mathrm{A}$ infections among public cleansing workers of Bangkok Metropolis. Hepat Mon. 2008;8(1):35-40.

29. Mariolis A, Mihas C, Magaziotou I, Alevizos A, Gizlis V, Papathanasiou M, et al. Seroepidemiological study of viral hepatitis among workers of the Cleaning Department of the Municipality of Vyronas: Preliminary results of a single centre study. Public Health. 2006;120(11):1088-9.

30. Ferreira JA, Tambellini AT, Silva CLP, Guimaraens MAAM. Hepatitis B Morbidity in Municipal and Hospital Waste Collection Workers in the City of Rio de Janeiro. Infect Control Hosp Epidemiol. 1999;20(9):591-2.

31. Heller L, Cairncross S. Poverty. In: Bartram J, Baum R, Coclanis PA, Gute DM, Kay D, McFadyen S, et al, editors. Routledge Handbook of Water and Health. New York: Routledge; 2015. p. 376-86.

32. Kelsey JL, Whittemore AS, Evans AS, Thompson WD. Methods in Observational Epidemiology. 2nd edition. New York: Oxford University Press; 1996. 432 p.

33. World Health Organization (WHO). Hepatitis B - Emergencies preparedness, response [Internet]. Acessed: March 2016. Available from: http://www.who.int/csr/disease/hepatitis/whocdscsrlyo20022/ en/

34. Ministéiro da Saúde (MS). Estudo de prevalência de base populacional das infecções pelos vírus das hepatites A, B E $\underline{\mathrm{C}}$ nas capitais do Brasil. Recife: Universidade de Pernambuco, Núcleo de Pós-Graduação; 2010. Disponível em: http://www.aids.gov.br/sites/ default/files/anexos/publicacao/2010/50071/estudo_prevalencia hepatites_pdf_26830.pdf.

35. Machado MRM, Machado FA. Acidentes com material biológico em trabalhadores de enfermagem do Hospital Geral de Palmas (TO). Rev Bras Saúde Ocup. 2011;36(124):274-81.

36. Lima LM, Oliveira CC, Rodrigues KMR. Exposição ocupacional por material biológico no Hospital Santa Casa de Pelotas - 2004 a 2008. Esc Anna Nery. 2011;15(1):96-102.

37. Özdelikara A, Tan M. Conditions in which nurses are exposed to the hepatitis viruses and precautions taken for prevention. Aust J Adv Nurs. 2012;30(1):33-41. 